\title{
O. Andrzej A. Napiórkowski OSPPE red. Wyjątkowość Kościota katolickiego, Uniwersytet Papieski Jana Pawła II w Krakowie, Wydawnictwo Naukowe, Kraków 2018, ss.252
}

W ciągu dwudziestu wieków o Kościele założonym przez Jezusa Chrystusa zostało już bardzo dużo powiedziane. Na temat Kościoła jako misterium, jego funkcjonowania, przeżywania sakramentów powstało wiele pozycji książkowych. Czy potrzeba było w dzisiejszych czasach, aby po raz kolejny zanurzać się w refleksjach na tematy eklezjalne?

Bez wątpienia Kościół jest czymś wyjątkowym, można powiedzieć kimś wyjątkowym. Jego specyfiką jest Bosko-ludzki wymiar. Dlatego bardzo ważne jest odkrywanie na nowo jego „charakteru”, który wyróżnia go i identyfikuje kościelność chrześcijańską na tle różnych idei, światopoglądów, różnych duchowości dzisiejszego świata.

W książce, która w większości jest zapisem ogólnopolskiej konferencji z 20 lutego 2018 roku w Krakowie pt. „Wyjątkowość Kościoła”, została przedstawiona tytułowa wyjątkowość Wspólnoty założonej przez Osobę Jezusa Chrystusa. Wyróżnia się ona spośród innych wyznań niezwykłym rozumieniem sakramentalności, ciągła sukcesją apostolską oraz szczególnym miejscem Najświętszej Maryi Panny w dziejach Zbawienia.

W pierwszym artykule (ss. 9-33) zredagowanym przez ojca Bazylego Degórskiego, dowiadujemy się o losach hierarchii Kościoła pierwszych wieków chrześcijaństwa. Okazuje się, że już najstarsze źródła pism chrześcijańskich wspominają biskupów i diakonów, których wybiera 
wspólnota chrześcijańska. W II wieku, począwszy od Ignacego z Antiochii, historia wspomina już o trójstopniowym podziale władzy, gdzie między biskupami i diakonami pojawiają się również prezbiterzy. Następnie w swojej wypowiedzi prelegent wyjaśnia motyw włożenia rąk jako gestu chrześcijańskiego. Wskazuje, że jest to najważniejszy gest wszystkich obrzędów.

Kolejny artykuł (ss. 34-56) napisany przez krakowskiego profesora Marka Kitę porusza problem Kościoła jako sposobu istnienia. Wychodząc od cytatu znanego prawosławnego teologa Ioannisa Zizioulasa, który brzmi:

Kościół nie jest po prostu instytucją. Jest rodzajem egzystowania, sposobem bycia. Tajemnica Kościoła, nawet w jego wymiarze instytucjonalnym, pozostaje głęboko związana $\mathrm{z}$ byciem człowieka, byciem świata oraz prawdziwym byciem Boga

ukazuje prawdziwie wspólnotowe funkcjonowanie człowieka w świecie. Żyć w Chrystusie to znaczy trwać w wewnętrznej i zewnętrznej więzi z innymi trwającymi w Panu. Autor stwierdza, że to wiara w Chrystusa i zawierzenie się Jemu w pełni, jest łaską bycia Kościołem. To Kościół staje się urzeczywistnieniem podstawowego przykazania Chrystusa, ucieleśnieniem wzajemnej miłości w życiu. Podkreślone zostało również znaczenie Soboru Watykańskiego II, który to przysłużył się do przeakcentowania eklezjologii łacińskiej z przesadnie hierarchicznej na taki o rysach komunijnych. To określenie Ludu Bożego staje się niezwykle istotne w eklezjologii. W swojej Eklezji Bóg zwołuje nas jako lud, a nie pojedyncze jednostki. Bóg - Komunia pociąga nas do siebie uwzględniając złożoną sieć relacji międzyludzkich, zbawia nas w relacjach i z relacjami. Doskonale koresponduje z pojęciem ludu symbol drogi. Całość życia wspólnotowego cechuje dynamizm bycia w ciągłym pielgrzymowaniu. Być Kościołem - stwierdza dr hab. Marek Kita - to być komunią wspólnej drogi. W ostatnim punkcie rozważania o sposobie istnienia pogłębiają się. Przeżywanie

Reports and reviews Kościoła jako Boskiego sposoby życia okazuje się być permanentnym wydarzeniem komunii, doświadczeniem drogi wespół i jednocześnie ciągłego wchodzenia coraz głębiej w wielowymiarową komunię osób.

Ksiądz Stanisław Kozakiewicz zajął się powagą Kościoła w nauczaniu Stanisława Hozjusza i Melchiora Cano (ss. 56-75). To wiara w Kościół wydaje się być największym problemem. Dlatego tė zaakcentowany zostaje fakt, że gdy tracimy więź z Bogiem, wtedy Kościół staje się zwykłą, ludzką strukturą pozbawioną jakichkolwiek Boskich odniesień. Staje się on wtedy być stworzonym na obraz ludzki, dla naszych małych potrzeb. Nie może więc dziwić fakt, że 
już w szesnastowiecznej Europie bronili nadprzyrodzonej jedności Kościoła z żywym Chrystusem tacy mężowie jak Stanisław Hozjusz i Melchior Cano. Obaj poświęcili całe życie obronie Kościoła. Jaka była powaga Kościoła w ich nauczaniu? Obaj nawoływali ludzi do powrotu niczym zagubione owce na łono owczarni Pańskiej. Podkreślali, że Kościół ma charakter chrystologiczny, nie jest ludzkim wymysłem, ale opiera się na autorytecie Jezusa Chrystusa. Wspólnota wtedy jest prawdziwa, kiedy nie odrzuca tych, którzy błądzą, ale mocą Ducha Bożego przemienia ich i doskonali. O szczególnej powadze Kościoła świadczy właściwe rozumienie samej nazwy oraz przynależności do niego nie tylko sprawiedliwych, ale i grzeszników, którzy zawsze mogą stać się sprawiedliwymi. O powadze Kościoła świadczą również dogmaty wiary formowane przez Magisterium Kościoła.

Profesor z Lublina, Krzysztof Leśniewski w swoim artykule (ss. 7689) podjął temat Kościoła jako ikony misterium Trójcy Przenajświętszej w teologii prawosławnej. Kościoła, który w rzeczywistości przekracza granice ludzkiego rozumienia. Dlatego w teologii prawosławnej podkreśla się, że jest on tajemnicą. Zdumiewa fakt braku potrzeby definiowania Kościoła, ale również brak wyodrębnionego traktatu eklezjologicznego. Ostatecznie przecież rzeczywistości Kościoła nie da się sprowadzić do poziomu doktryny, gdyż stanowi ona coś więcej. W swojej pracy autor podkreśla jedność Trójcy Świętej jako fundamentu Kościoła. Misją wierzących jest dawanie świadectwa jedności. Bóg bowiem daje się poznać jako doskonała wspólnota Trzech Osób. Kontemplacja prawdy o Kościele jest nierozerwalnie związana z kontemplacją Trójcy Świętej.

Ksiądz Antoni Nadbrzeżny w kolejnym artykule (ss. 90-107) przypomniał wszystkim, że Kościół nie tylko strzeże depozytu siedmiu sakramentów, ale również sam może być tak nazywany. Współczesna eklezjologia podkreśla, że człowiek od samego początku miał w sobie potężną tęsknotę za jakimś bezpośrednim kontaktem z Transcendencją. Sakramentalna struktura i funkcja Kościoła nie może być nigdy rozpatrywana w oderwaniu od historycznej osoby Jezusa Chrystusa. Ukazywanie Kościoła jako sakramentu Zbawienia w świecie i dla świata musi być połączone z Nim, aby nie prowadzić do błędnego eklezjocentryzmu. Według współczesnej teologii powstanie Kościoła nie odnosi się do jakiegoś jednego momentu w historii, ale stanowi owoc całego bytu Chrystusa, Jego historii, egzystencji, słów i działań.

Następny artykuł (ss. 108-130) pióra, o. Andrzej Napiórkowski opisuje misteryjną zbawczość Kościoła katolickiego. Autor podjął próbę odpowiedzi na pytanie: czy Zbawienie może być dostępne wszystkim 
ludziom? Przypomniał historyczny kontekst skomplikowanej kwestii osiągnięcia Zbawienia jak też wypowiedzi niektórych teologów oraz ukazał wkład nauczania soborowego. Ważna również stała się analiza porównująca różne religie z chrześcijaństwem oraz zmiany, jakie dokonywały się w myśleniu o zakresie Zbawienia. Uświadomienie sobie daru, którym jest Zbawienie powinno kształtować wśród ludzi postawę wdzięczności za Kościół, gdzie Zbawienie jest przechowywane i sakramentalnie udzielane.

Kościół świętych, czyli o wyjątkowości eklezjologii Hansa Ursa von Balthasara napisał ks. Paweł Pielka (ss. 131-144). Eklezjologia kształtowana z zasady jako reakcja na herezję czy inny kryzys w Kościele w konsekwencji musiała nosić w ciągu wieków znamię pewnej jednostronności. Idąc za zdaniem Balthasara, autor pragnie przywrócić świętym autorytet Kościoła, gdyż to właśnie oni wiedzą o Bogu najwięcej. Cała świętość Kościoła uosobiona jest w szczególności na świętości ludzi, którzy odzwierciedlają Jezusa Chrystusa. Bóg przez świętych z upodobaniem uczestniczy w historii Kościoła. Święci nam pomagają dochodzić do Boga, są jego ekspertami, wiedzą o Nim najwięcej. Kościół potrzebuje właśnie takich świadków, aby sprostać ponadludzkiemu zadaniu, które stoi przed każdym człowiekiem. W ostatnim punkcie prelegent wymienia dary, którymi święci obdarzają całą Wspólnotę. Zapatrzeni w świętych mamy współdziałać, by Kościół stawał się coraz bardziej wyjątkowym.

Ksiądz Piotr Rossa opisał znaki świętości Kościoła (ss. 145-166). Podkreślił, że na owczarnię Chrystusową nie możemy patrzeć jedynie po ludzku, charakteryzuje się on przede wszystkim Bosko-ludzkim kształtem. Ksiądz profesor przypomina prawdę, że to Bóg udziela swojej świętości ludziom. Przedstawia w sposób zwięzły historię Zbawienia - szczególnego momentu działania Boga. Następnie autor wymienia podstawowe obrazy, które w ciągu wieków zostały wypracowane na określenie świętości Kościoła. Warto zwrócić uwagę na znane

Reports and reviews określenia Ciała Chrystusowego, pojęcia Oblubieńca i Oblubienicy czy też znaku świątyni Ducha Świętego. Żaden z przywołanych obrazów Kościoła nie wyczerpuje jednak całej jego tajemnicy i domaga się czynienia lektury wraz z pozostałymi, aby pełniej wyrazić misterium tej Bosko- ludzkiej wspólnoty. Świętość Kościoła realizuje się $\mathrm{w}$ powiązaniu z elementem ludzkim, historycznym i naznaczonym słabością codzienności. Autor ciekawie podkreśla, że świętość Kościoła ma swoje źródło w świętości Boga. Udziela On swojej świętości wszystkim w osobie Jezusa Chrystusa. Wyraźnym znakiem świętości 
każdego miejsca i czasu są wierni, poprzez swoje świadectwo życia, jak też święci Kościoła.

Kwestia wyjątkowości Kościoła może być ujmowana na różne sposoby. W kolejnym opracowaniu owa wyjątkowość została opisana w perspektywie wiary przez o. Romana Słupka (ss. 167-187). Specyfikę Wspólnoty chrześcijańskiej jako środowiska wiary widzieć należy jako zjednoczoną z naturą wiary chrześcijańskiej - jej eklezjalnym charakterem. Specyfika ta jest możliwa do ukazania na podstawie rozumienia Kościoła jako matki naszej wiary i tajemnicy jego macierzyństwa. Wiara, będąca osobistą odpowiedzią na uprzedzające działanie Boga, stanowi fundament eklezjalnej wspólnoty. Kościół jest zgromadzeniem tych, którzy z wiarą spoglądają na osobę Jezusa Chrystusa. Rodzi się on z odpowiedzi wiary, jaką Mu dajemy. Pierwotne więc jest działanie i słowo Boga. Na mocy tego może dopiero zrodzić się eklezjalne działanie i mówienie. To ostatecznie sam Chrystus jest źródłem i gwarantem skutecznego rodzenia do wiary oraz wyjątkowości Kościoła jako środowiska wiary.

Ksiądz Piotr Szczur w swoim artykule ukazał wyjątkowość pozycji św. Piotra w Kościele na podstawie wypowiedzi Jana Chryzostoma (ss. 188-207). Spośród Apostołów to właśnie On został wyraźnie wyróżniony. Jego pozycja opisana jest przez złotoustego w rozmaity sposób. Według Chryzostoma jedną z przyczyn wyróżnienia Piotra oraz tego, że miał on znaczącą pozycję w gronie Apostołów, była jego gorliwość i wiara. Uwadze złotoustego kaznodziei nie umyka też fakt, że Piotr wiele wycierpiał dla Chrystusa i Kościoła. Następnie Ksiądz profesor zatrzymuje refleksję na temacie prymatu św. Piotra na tle wszystkich Apostołów. Piotr ma realną władzę i decyduje o wszystkim, co dzieje się w Kościele apostolskim.

Tematem, jaki porusza w swoim artykule ks. Jerzy Szymik jest eklezjologia Ratzingera / Benedykta XVI (ss. 208-222). W szczególny sposób podkreśla nasze współuczestnictwo w dziele budowania doczesności wierzących. W piękny sposób zostało opisane w tym artykule powszechne zaproszenie nas wszystkich do wspólnoty z Bogiem, które objawia się we wspólnocie z człowiekiem. Kościól jest braterstwem wierzących ludzi. Kościół jest Bożą rodziną, a przez Ojca chronione są Jego dzieci. Kościół jest żywym organizmem, w którym tętni życie z całą jego złożonością.

Ostatni artykuł zredagowała mgr Magdalena Żyła opisując wyjątkowość Kościoła według Adrienne Von Speyr (ss. 223-246). Niezwykłość Królestwa Bożego polega na jego sakramentalności, z akcentem położonym na Eucharystię i spowiedź, a także na maryjności. 
W rzeczywistości Ludu Bożego istotnym jest fakt, iż pomimo jego więzi z Bogiem, każdy nadal pozostaje wolny w swym sumieniu, który sam musi stanąć przed Bogiem. Staje się On promieniowaniem Zmartwychwstałego Jezusa Chrystusa w dzisiejszym świecie.

Kościół poprzez wciąż dynamiczną strukturę aktualizuje swoje bytowanie w świecie, dlatego niezwykle cenna jest pozycja książkowa pod redakcją o. Andrzeja Napiórkowskiego, ukazująca dzięki zaangażowaniu wielu teologów nową jego odsłonę. Kościół jako rzeczywistość Bosko-ludzka zachowuje ciągle strukturę misterium do odkrycia, a ta publikacja na pewno o tym przypomina i daje kolejne argumenty. 